\title{
GROWTH TREND OF RICE DEMAND AND SUPPLY IN NIGERIA: AN INVESTMENT OPPORTUNITY FOR YOUTH AND WOMEN EMPOWERMENT
}

\author{
Oyakhilomen Oyinbo, Maiyaki Abdullahi Damisa, Grace Zibah Rekwot, Researchers \\ Department of Agricultural Economics and Rural Sociology \\ Ahmadu Bello University, Zaria, Nigeria \\ Email: ooyinbo@abu.edu.ng
}

\begin{abstract}
This study was carried out to determine the instantaneous and compound growth rates of rice demand and supply in Nigeria over the period of 1970 to 2011 and its implication for empowering youths and women. Time series data on the aggregate rice demand and supply obtained from the database of United State Department for Agriculture (USDA) foreign agricultural service were utilized in this study. A growth rate model was employed to analyse the time series data and the result of the analysis showed that the instantaneous and compound growth rates $(7.5 \%$ and $7.8 \%)$ of rice demand were higher than that of rice supply $(6.5 \%$ and $6.7 \%)$ and this indicates that the incidence of demand-supply gap for rice in Nigeria has been an existing trend over the years and the trend would continue if appropriate measures are not taken despite the country's huge potential for rice production to attain selfsufficiency. The implication of this finding is that the untapped potential of Nigeria for rice production should be exploited for the empowerment of youths in the area of rice production and women in the area of rice processing.
\end{abstract}

\section{KEY WORDS}

Growth; Demand; Supply; Rice; Women; Youth.

Rice is a leading staple crop in Nigeria that is cultivated and consumed in all parts of the country (Ayanwale et al., 2011). During the 1960s, Nigeria had the lowest per capita annual consumption of rice in the sub-region at an annual average of $3 \mathrm{~kg}$. Since then, Nigerian per capita consumption levels have grown significantly at $7.3 \%$ per annum. Consequently, per capita consumption during the 1980s averaged $18 \mathrm{~kg}$ and then $22 \mathrm{~kg}$ in 1995-2000 (Ogundele and Okoruwa, 2006). In Nigeria, rice has assumed a strategic position in the food basket of rural and urban households and is cultivated in virtually all of Nigeria's agro-ecological zones, from the mangrove and swampy ecologies of the River Niger delta in the coastal areas to the dry zones of the Sahel in the north. The demand for rice in Nigeria has been increasing at a much faster rate than in any other African country since the mid1970s (Daramola 2005). Although the paddy harvest rose from under 1 million tonnes in the 1970s to 4.2 million tonnes in 2010, production has not kept pace with demand. There is considerable potential for extending and intensifying rice production in the five rice-growing ecosystems found in Nigeria (plateau, rained plains, irrigated plains, lowlands and mangrove), Bamba et al. (2010). The land area that could be cultivated is roughly 79 million hectares. Less than $10 \%$ of the 3.4 million hectares that could be irrigated are currently irrigated.

Self-sufficiency in rice production has eluded Nigeria for a long time despite over 36 years of efforts by the Government of Nigeria towards its realization (Umeh and Atarboh, 2007). The importation of rice to bridge the demand-supply gap is worth 1365 billion (Ayanwale and Amusan, 2012) and this implies a loss of considerable foreign exchange for the country. Several researches on the rice sub-sector of Nigeria have been undertaken over the years but not much have been done on the growth trend of rice with particular emphasis on the instantaneous(yearly) growth rate and compounded(aggregate of several years) growth rate of the demand as well as supply of rice in Nigeria. Therefore, this study was designed to provide empirical information on the instantaneous and compounded growth rates of rice demand and supply over the period of 1970 to 2007 and draw up relevant inferences. 


\section{METHODOLOGY}

Data description. This study employed time series data on the demand of rice given by rice consumption in metric tonnes and supply of rice given by milled rice production in metric tonnes in Nigeria spanning over the period of 1970 to 2011. The data were elicited from the database of United State Department for Agriculture (USDA) foreign agricultural service.

Model Specification. A growth rate model adopted from (Gujarati and porter, 2009) and as used by Khalid and Burhan (2006) and Oyinbo and Emmannuel (2012) was utilized for the estimation of growth trend in rice demand supply in Nigeria over the period of 1970 to 2011. The compound interest formula was adopted for developing the model and is expressed as:

$$
Y_{t}=Y_{0}(1+r)^{t} \ldots(1),
$$

where: $Y_{t}=$ Rice demand and supply (metric tonnes); $Y_{0}=$ Initial value of rice demand and supply (metric tonnes); $r=$ Compound rate of growth of rice demand and output over time; $t=$ Time trend (1970 to 2011).

Taking the natural logarithm of equation (1), equation (2) was derived as:

$$
\ln Y_{t}=\ln Y_{0}+\operatorname{tnn}(1+r) \ldots(2),
$$

where: $a_{0}=\ln Y_{0}, a_{1}=\ln (1+r)$.

Equation (2) is rewritten as:

$$
\ln Y_{t}=a_{0}+b_{1} t \ldots .(3)
$$

Adding disturbance term to equation (3), the explicit form of the model employed was derived as:

$$
\ln Y_{t}=a_{0}+a_{1} t+u_{t} \ldots(4)
$$

where: $Y_{t}=$ Rice demand and supply (metric tonnes); $t=$ Time trend (1970 to 2011); $a_{0}=$ constant term; $a_{1}=$ Coefficient of time variable; $u_{t}=$ Random term. follows:

After the estimation of equation (1), the compound rate of growth was computed as

$$
r=\left(e^{a_{1}}-1\right) \ldots(5),
$$

where: $r=$ compound rate of growth; $a_{1}=$ estimated coefficient from equation (1).

The explicit form of the growth rate model as shown in eq. (4) was estimated using SHAZAM statistical software.

\section{RESULTS AND DISCUSSION}

The result obtained from the estimation of the growth model for rice demand and supply is presented in Table 1. The result shows that time trend variable was significant in influencing demand and supply of rice at $1 \%$ probability level and the relationship was positive in the rice demand and supply growth models. In the estimated growth rate models, the slope coefficients of 0.075 and 0.065 for rice demand and supply respectively measures relative change in quantity demanded and supplied for a given change in the value of time trend. By multiplying the relative change in quantity of rice demanded and supplied respectively by hundred, we obtained the percentage change or the growth rate in quantity of rice demanded and supplied for an absolute change in time.

Rice demand:

$$
\begin{gathered}
\text { Growth rate }=\text { relative change } \times 100 \\
\text { Growth rate }=0.075 \times 100 \\
\text { Growth rate }=7.5 \%
\end{gathered}
$$


Rice supply:

$$
\begin{gathered}
\text { Growth rate }=\text { relative change } \times 100 \\
\text { Growth rate }=0.065 \times 100 \\
\text { Growth rate }=6.5 \%
\end{gathered}
$$

\begin{tabular}{|c|c|c|c|}
\hline Variable & Coefficient & S.E & $t$-value \\
\hline \multicolumn{4}{|c|}{ Rice demand } \\
\hline Constant $\left(a_{0}\right)$ & -51.374 & 2.729 & -18.83 \\
\hline Time $\left(a_{1}\right)$ & 0.075 & 0.004 & 21.17 \\
\hline R square & 0.95 & - & - \\
\hline \multicolumn{4}{|c|}{ Rice supply } \\
\hline Constant $\left(a_{0}\right)$ & -44.919 & 2.900 & -15.49 \\
\hline Time $\left(a_{1}\right)$ & 0.065 & 0.003 & 25.30 \\
\hline R square & 0.92 & - & - \\
\hline
\end{tabular}

Table 1 - Estimated growth model of rice demand and supply in Nigeria*

${ }^{*} P<0.01$

The growth rates of $7.5 \%$ and $6.5 \%$ for rice demand and supply respectively implies that over the period of 1970 to 2011 , the demand and supply of rice in Nigeria increased at the rate of $7.5 \%$ and $6.5 \%$ per annum. However the growth rate worked out are an instantaneous (at a point in time) rate of growth and not the compound (over period of time) rate of growth. Compound growth rates $(r)$ were estimated from the instantaneous rates of growth, in that $7.5 \%$ and $6.5 \%$ are instantaneous growth rates:

$$
\begin{gathered}
\ln (1+r)=a_{1} \\
r=\text { Antilna }_{1}-1 \\
r=\left(e^{a_{1}}-1\right) \times 100
\end{gathered}
$$

Rice demand:

$$
r=\left(e^{0.075}-1\right) \times 100
$$

Rice supply:

Compound rate of growth $(r)=7.8 \%$

$$
\begin{gathered}
r=\left(e^{0.065}-1\right) \times 100 \\
\text { Compound rate of growth }(r)=6.7 \%
\end{gathered}
$$

Therefore, the growth trend of rice demand and supply in Nigeria per annum within the period under study(instantaneous rates of growth) are $7.5 \%$ and $6.5 \%$ respectively and the rate of growth of rice demand and supply in Nigeria over the entire period under study(compound rates of growth) are $7.8 \%$ and $6.7 \%$ respectively. It was observed that the instantaneous and compounded growth rates of rice demand in Nigeria over the study period were higher than that of rice supply. This finding is in line with Ojoehemon et al. (2009), who noted that both rice production and consumption have vastly increased with rice demand outstripping rice production. The $7.5 \%$ per annum growth rate estimated in this study is closely related to the $7 \%$ per annum used to make a projection of rice demand of 35 million tonnes in 2050 (Ayanwale and Amusan, 2012). The result of this study indicates that the rice demand-supply gap scenario have been an existing trend that would continue if appropriate measures are not taken.

The higher instantaneous and compounded growth rates of rice demand over rice supply imply that there would be continuous importation of rice to bride the demand-supply gap and this is detrimental to the Nigerian economy. As noted by Bamba et al., (2010), the cost of rice imports represents a significant amount of lost earnings for the country in terms of jobs and income. Therefore, the on-going trend offers an opportunity for youths to be empowered to undertake rice production and for women to be empowered by getting involved in rice processing. This is necessary to reduce the incidence of social vices resulting from the increasing rate of unemployment and offer a sustainable means of livelihood for 
resource poor women and achieve self-sufficiency in rice production. This calls for capacity building of youths on rice production and women on rice processing. As reported by Gingiyu (2012), about 400 women drawn from 9 states of the North-west have been trained by the federal ministry of agriculture and rural development on modern rice processing techniques during a three-day workshop for women in agriculture. This is a laudable effort that needs to be consolidated and spread to other geopolitical zones of the nation.

\section{CONCLUSION}

Using time series data on rice demand and supply over the period of 1970 to 2011, this study have been able to establish the instantaneous and compounded growth rates of $7.5 \%$ and $7.8 \%$ respectively for rice demand and $6.5 \%$ and $6.7 \%$ for rice supply using growth models. The results indicated that the demand-supply gap for rice has been an existing trend irrespective of the country's potential for rice production. The growth trend of the demand and supply for rice offers a viable option for empowering youths in the area of rice production and women in the area of rice processing. This will stem down the incidence of social vices resulting from high rate of unemployment, offer a sustainable means of livelihood for resource poor women and foster attainment of self-sufficiency in rice production.

\section{REFERENCES}

[1] Ayanwale, A.O.S., Akinyosoye, V.O., Yusuf, S.A. and Oni, A.O. (2011) Rice Supply Response in Nigeria; whither changing Policies and Climate. World Rural Observations, 3(4): $78-84$.

[2] Ayanwale, A.B. and Amusan, C.A.(2012). Gender Analysis of Rice Production Efficiency in Osun State: Implication for the Agricultural Transformation Agenda. Paper presented at the 13th National Conference of the Nigerian Association of Agricultural Economists, Obafemi Owolowo University, Ile - Ife, Nigeria, September 25th - 27th.

[3] Bamba, I., A. Diagne, Manful, J.and Ajayi, A.( 2010). Historic Opportunities for Rice Growers in Nigeria. Grain de sel. No. 51, July - September 2010.

[4] Daramola, B. (2005). Government Policies and Competitiveness of Nigerian Rice Economy, Paper presented at the 'Workshop on Rice Policy and Food Security in SubSaharan Africa' organized by WARDA, Cotonou, Republic of Benin.

[5] Gingiyu, I.M.(2012). Nigeria: FG Trains Women on Modern Rice Processing Techniques. Available at: http://allafrica.com/stories/201212121037.html. Accessed $12^{\text {th }}$ January 2013.

[6] Gujarati, D.N. and Porter, C. D. (2009). Basic Econometrics (5th Edition). McGraw-Hill, New York.

[7] Khalid, M. and Burhan, A. (2006). An econometric model for forecasting export of Kinnow from Pakistan. International Journal of Agriculture and Biology, 8(2): 459 - 462.

[8] Ogundele O. and Okoruwa V. (2006), Technical Efficiency Differentials in Rice Production Technologies in Nigeria, African Economic Research Consortium.

[9] Ojehomon, V.E.T., Adebayo, S.B., Ogundele, O.O., Okoruwa, V.O., Ajayi, O., Diagne, A. and Ogunlana, O. (2009). Rice Data Systems in Nigeria: National Rice Survey.

[10] Oyinbo, O. and Emmaduel, Y.D. (2012). Empirical Assessment of Growth Rate of Maize in the Pre - SAP, SAP and Post - SAP Periods in Nigeria, Russian Journal of Agricultural and Socio-Economic Sciences, 5(5): $23-27$.

[11] Umeh, J.C. and Atarboh, E.M. (2007). Efficiency of Rice Farmers in Nigeria: Potentials For Food Security and Poverty Alleviation. 16th International Farm Management Congress, UCC, Cork, Ireland. $15^{\text {th }}-20^{\text {th }}$ July 2007. pp: $613-625$.

[12] United States Department for Agriculture Foreign Agricultural Services(USDA FAS), 2011. Database of production, supply and distribution. Available at: http://www.fas.usda.gov/psdonline/psdQuery.aspx > Accessed 15th December 2011. 